\title{
IDENTIFIKASI KESULITAN MAHASISWA DALAM PEMBELAJARAN BIOLOGI MOLEKULER BERSTRATEGI MODIFIED FREE INQUIRY
}

(Identification of Student Difficulties in Molecular Biology with Modified Free Inquiry Learning Strategy)

\section{Evi Suryanti $^{* * *}$ Any Fitriani*) Sri Redjeki*) Riandi $^{*}$}

*) Pendidikan IPA, Sekolah Pascasarjana, Universitas Pendidikan Indonesia, Bandung

**) Pendidikan Biologi, FKIP, Universitas Islam Riau, Pekanbaru

\begin{abstract}
The aim of this study was to identify the difficulties learning by students in the modified free inquiry learning strategy of Molecular Biology and the causes of these difficulties. The method used is descriptive with a questionnaire technique. Respondents are 51 Biology Education students who contracted the Molecular Biology course in Academic Year 2017/2018 at one of the education institution in Kota Pekanbaru. The stages in the modified free inquiry strategy that are carried out consist of steps: 1) orienting students to the topics discussed by giving direct questions, 2) students make questions as the formulation of the problem, 3) proposing hypotheses, 4) collecting data and information for testing hypotheses, 5) communicating findings, and 6) concluding. Topics covered were DNA isolation, agarose gel electrophoresis, and polymerase chain reaction (PCR) and in the lectures were complemented by wet and virtual laboratory activities. Research instruments in the form of a closed questionnaire with answer choices 'yes' and 'no'. Data analyzed are presented in the form of percentage figures. The results of data analysis showed that: (1) Students who experienced difficulty in learning Molecular Biology with a modified free inquiry strategy were $45.10 \%$ and those who did not experience difficulties were 54.90\%; (2) The causes of difficulties are limited time (78.26\%), not finding adequate learning resource materials (39.13\%), unable to understand the learning resource materials found (39.13\%), unable looking for adequate learning resource materials (21.74\%), and not interested in the modified free inquiry strategy (17.39\%); and (3) most students agree to apply the modified free inquiry strategy to other biology courses. The implication of the research is the modified free inquiry strategy can be applied in biology learning at the university level.
\end{abstract}

Key words: learning difficulties, molecular biology, modified free inquiry strategy 


\section{PENDAHULUAN}

Biologi molekuler merupakan salah satu bidang inovasi ilmiah dan teknis yang paling cepat berkembang, dan memiliki efek mendalam pada berbagai aspek kehidupan sehari-hari. Konten Biologi Molekuler adalah kompleks, sangat abstrak, dan berakar pada beragam disiplin ilmu mulai dari pure sciences (matematika, kimia, dan fisika) hingga applied sciences (kedokteran dan pertanian) (Tibell dan Rundgren, 2010). Rotbain, dkk. (2008) juga berpendapat bahwa kebanyakan konsep dan proses dalam biologi molekuler adalah abstrak. McClean, dkk. (2005) menjelaskan dalam artikelnya bahwa mahasiswa sering kesulitan untuk memahami kompleksitas dan saling keterkaitan proses dalam konten Biologi Molekuler. Sebagai contoh, mahasiswa mengetahui bahwa proses penting seperti transkripsi RNA melibatkan polimerase RNA, tapi fakta bahwa polimerase RNA itu sendiri sebenarnya merupakan suatu kompleks protein multimerik sering tidak dipahami oleh siswa. Siswa juga mungkin tidak memahami bahwa polimerase RNA tidak beraksi sendiri, melainkan salah satu komponen dari proses transkripsi yang melibatkan beberapa kompleks multiprotein, dan masing-masing kompleks memainkan peranan yang penting dalam produksi RNA.

Hasil penelitian Nurlaila, dkk. (2017) terhadap mahasiswa Pendidikan Biologi diketahui bahwa mahasiswa mengalami miskonsepsi pada konsepkonsep genetika molekuler seperti DNA $(23.75 \%)$, gen $(18.75 \%)$ kromosom $(15 \%)$ dan sintesis protein (5.5\%). Di samping itu, hasil penelitian Boulay, dkk. (2010) menemukan bahwa para guru tidak mengajarkan teknik-teknik biologi molekuler tertentu di kelas karena kurang percaya diri. Teknik-teknik tersebut seperti pemipetan, sentrifugasi, elektroforesis DNA, purifikasi DNA/plasmid, ligasi DNA, restriction enzyme digestion of DNA, purifikasi protein, western blotting, transformasi bakteri, polymerase chain reaction, penggunaan spektrofotometer, immunostaining, pengkulturan sel, tissue sectioning, dan mikroskopi. Hasil studi Ozcan, dkk. (2014) terhadap siswa pendidikan dasar diketahui bahwa partisipan mempunyai kesulitan belajar salah satunya pada materi DNA dan kode genetik. Kesulitan belajar dari aspek subjek materi yaitu materi terlalu rumit dan terperinci, sulit, matematis dan memerlukan hapalan; dari aspek siswa yaitu tidak hadir, tidak belajar, dan tidak memahami; dari aspek guru (guru tidak hadir di kelas, mengajar tidak baik, membahas materi dengan cepat); dan tidak tertarik dengan mata pelajaran biologi, tidak ada bahan/materi visual yang digunakan; tidak ada eksperimen; materi tidak terkait dengan kehidupan sehari-hari, dan baru bagi siswa. Pada pendidikan lanjutan materi yang sulit bagi siswa di antaranya adalah struktur DNA dan replikasi, bioteknologi dan rekayasa genetika. Alasan terhadap kesulitan belajar adalah tidak ada hubungan antar konsep yang terbentuk; tidak terkait dengan kehidupan sehari-hari; materi memerlukan hapalan; tidak ada materi visual yang digunakan; materi terlalu panjang dan mendalam; dan tidak tertarik terhadap subjek tersebut.

Temuan-temuan penelitian tersebut memperlihatkan keterbatasan dalam kurikulum Biologi Molekuler yang menyebabkan mahasiswa kesulitan untuk memahami kompleksitas yang mendasari proses molekuler dan seluler yang penting dalam kebanyakan konten Biologi Molekuler. Keadaan tersebut menjadi tantangan bagi pendidik biologi untuk membelajarkan Biologi Molekuler dengan strategi yang tepat agar kompleksitas proses-proses biologi pada tingkat molekuler tersebut dapat dipahami dengan mudah oleh peserta didik. Salah satu model pembelajaran yang direkomendasikan di dalam Kurikulum 2013 adalah inkuiri. The National Science Education Standards (NSES) mendefinisikan inkuiri sebagai aktivitas 
multiarah dimana siswa melakukan observasi, bertanya, mengumpulkan informasi dari berbagai sumber, merencanakan dan melakukan investigasi, menggunakan bukti untuk menjelaskan pertanyaan, menggunakan peralatan untuk mencari, mengumpulkan dan menginterpretasi data; mengusulkan jawaban, pertanyaan, dan prediksi; dan mengomunikasikan temuan (NRC,1996).

Inkuiri menjadi tujuan penting dari pendidikan sains selama beberapa dekade (Quigley, dkk., 2011). Penerapan inkuiri dalam ranah pendidikan dan pembelajaran sains memiliki berbagai istilah, seperti inquiry-based instruction (Martell, 2019; Gormally, dkk., 2011; van Hook, dkk., 2009), inquiry-based learning (Duran dan Dökme, 2016; Wu, dkk., 2014; DeBoer, 2000), inquiry-based science teaching (Fitzgerald, dkk., 2017; Lee dan Shea, 2016), dan inquiry-based science education (van Uum, dkk., 2016). Pembelajaran inkuiri menawarkan strategi, nilai, dan sikap yang penting seperti: (a) keterampilan mengolah (mengobservasi, mengumpulkan dan mengolah data; mengidentifikasi dan mengontrol variabel; merumuskan dan menguji hipotesis, menjelaskan; menyimpulkan),

pembelajaran aktif dan mandiri, (c) pengungkapan verbal, (d) toleran pada ambiguitas, (e) berpikir logis, (f) sikap yang meyakini bahwa semua pengetahuan bersifat tentatif (Joyce, dkk., 2009). Model pembelajaran inkuiri memadukan beberapa keterampilan mengolah ke dalam satu unit pengalaman yang bermakna dan menawarkan pembelajaran yang aktif dan otonom terutama saat pelajar merumuskan pertanyaan dan menguji gagasan. Walaupun penekanannya pada proses, inkuiri juga berpengaruh terhadap pembelajaran materi dalam semua bidang kurikulum berdasarkan sudut pandang masalah yang dipilih. Pengajaran berbasis inkuiri dipromosikan secara luas untuk meningkatkan pemahaman konseptual pelajar dan keterlibatan mereka dalam konten materi (Gormally, dkk., 2011).
Terkait dengan keunggulan pembelajaran inkuiri maka selayaknya jika calon guru biologi dibekali dengan pengetahuan dan pengalaman tentang strategi pembelajaran inkuiri sehingga memiliki keterampilan dan kemampuan untuk berinkuiri. Faktanya strategi pembelajaran inkuiri memang telah banyak diaplikasikan dalam pembelajaran sains terutama inkuiri terbimbing (guided inquiry), dan terbukti telah memberikan kontribusi positif terhadap peningkatan kualitas proses dan hasil belajar sains. Berdasarkan kajian literatur belum banyak ditemukan penerapan inkuiri dalam pembelajaran Biologi Molekuler, khususnya strategi free inquiry. Menurut Roth (1995) ciri pembelajaran free inquiry adalah siswa merumuskan masalah mereka sendiri, menghubungkan pembelajaran mereka dengan pengetahuan sebelumnya, dan bekerja secara kolaboratif dengan berbagi dan berdiskusi bersama teman sebaya sehingga siswa termotivasi secara intrinsik untuk belajar. Berdasarkan bobot matakuliah dan fasilitas laboratorium maka langkah-langkah pembelajaran free inquiry telah dimodifikasi sehingga diharapkan lebih praktis dalam pelaksanaan pembelajarannya. Dengan demikian, tujuan penelitian ini adalah untuk: (1) Mengetahui apakah mahasiswa mengalami atau tidak mengalami kesulitan dalam pembelajaran Biologi Molekuler berstrategi modified free inquiry, (2) Mengidentifikasi penyebab kesulitan yang dialami mahasiswa, dan (3) Menggali pendapat mahasiswa tentang prospek penerapan strategi pembelajaran modified free inquiry dalam matakuliah biologi lainnya.

\section{METODE PENELITIAN}

Penelitian ini merupakan penelitian deskriptif yang bertujuan untuk mengidentifikasi kesulitan-kesulitan yang dialami mahasiswa terkait dengan pembelajaran Biologi Molekuler berstrategi modified free inquiry. Subyek penelitian adalah mahasiswa Pendidikan 
Biologi di salah satu LPTK di Kota Pekanbaru yang mengontrak matakuliah Biologi Molekuler (2 SKS) pada Tahun Akademik 2017/2018 sebanyak 69 orang terdiri 3 orang laki-laki dan 66 orang perempuan, namun jumlah mahasiswa yang mengembalikan angket sebanyak 51 orang.

Tahapan dalam strategi pembelajaran modified free inquiry yang dilaksanakan terdiri dari langkah-langkah: 1) mengorientasikan mahasiswa kepada topik yang dibahas dengan memberikan pertanyaan-pertanyaan pengarah, 2) mahasiswa membuat pertanyaan sebagai rumusan masalah, 3) mengajukan hipotesis, 4) mengumpulkan data dan informasi untuk menguji hipotesis, 5) mengomunikasikan temuan, dan 6) menyimpulkan. Topik yang dibahas yaitu Isolasi DNA, Elektroforesis gel agarosa, dan Polymerase chain reaction (PCR). Pembahasan topik Isolasi DNA dilengkapi dengan kegiatan wet laboratory dengan memanfaatkan fasilitas laboratorium yang terbatas; topik Elektroforesis dilengkapi dengan kegiatan wet laboratory (penyediaan gel agarosa) dan virtual laboratory (penyiapan DNA untuk elektroforesis dan running elektroforesis); dan pembahasan topik PCR juga dilengkapi dengan virtual laboratory. Aplikasi virtual laboratory dikembangkan sebagai solusi alternatif untuk mengatasi keterbatasan fasilitas laboratorium yang mendukung pembelajaran Biologi Molekuler.

Instrumen penelitian adalah angket tertutup yang diberikan setelah pembelajaran Biologi Molekuler berakhir. Angket divalidasi secara logis oleh dua orang dosen Pendidikan Biologi dan satu orang dosen Biologi. Angket terdiri dari tujuh pertanyaan dengan pilihan jawaban 'Ya' dan 'Tidak'. Pertanyaan-pertanyaan pada angket sebagai berikut:

1. Secara umum, apakah Anda merasakan kesulitan mengikuti pembelajaran Biologi Molekur dengan strategi modified free inquiry?
2. Jika Anda merasakan kesulitan, apakah penyebab kesulitan itu karena pelaksanaan pembelajaran yang terbatas waktunya?

3. Jika Anda merasakan kesulitan, apakah penyebab kesulitan itu karena Anda tidak mampu mencari bahan-bahan sumber belajar yang memadai?

4. Jika Anda merasakan kesulitan, apakah penyebab kesulitan itu karena Anda tidak menemukan bahan-bahan sumber belajar yang memadai?

5. Jika Anda merasakan kesulitan, apakah penyebab kesulitan itu karena Anda tidak bisa memahami bahan-bahan sumber belajar yang Anda temukan?

6. Jika Anda merasakan kesulitan, apakah penyebab kesulitan itu karena Anda tidak tertarik dengan strategi modified free inquiry?

7. Jika Anda tidak merasakan kesulitan, apakah Anda setuju jika strategi pembelajaran modified free inquiry diaplikasikan juga untuk matakuliah biologi lainnya?

Analisis data dilakukan dengan menghitung jumlah jawaban pada setiap opsi 'Ya' atau 'Tidak', lalu membaginya dengan jumlah mahasiswa responden dan mengalikannya dengan angka 100; sehingga diperoleh data jawaban responden dalam bentuk angka persentase. Pengolahan data dilakukan dengan bantuan program komputer Excel.

\section{HASIL}

Berdasarkan pengolahan dan analisis data diperoleh hasil seperti pada Tabel 1:

Tabel 1. Persentase jawaban mahasiswa pada setiap pertanyaan

\begin{tabular}{ccc}
\hline $\begin{array}{c}\text { Pertanyaan } \\
\text { nomor }\end{array}$ & \multicolumn{2}{c}{ Jumlah jawaban (\%) } \\
\cline { 2 - 3 } & Ya & Tidak \\
\hline 1 & $23(45,10)$ & $28(54,90)$ \\
\hline 2 & $18(78,26)$ & $5(21,74)$ \\
\hline 3 & $5(21,74)$ & $18(78,26)$ \\
\hline 4 & $9(39,13)$ & $14(60,87)$ \\
\hline 5 & $9(39,13)$ & $14(60,87)$ \\
\hline 6 & $4(17,39)$ & $19(82,61)$ \\
\hline 7 & $23(82,14)$ & $5(17,86)$ \\
\hline
\end{tabular}


Data pada Tabel 1 menunjukkan bahwa untuk pertanyaaan nomor 1 jumlah mahasiswa yang mengalami kesulitan dengan yang tidak mengalami kesulitan dalam mengikuti pembelajaran Biologi Molekur dengan strategi modified free inquiry hampir sama banyak. Untuk lebih jelasnya perbandingan antara mahasiswa yang mengalami dengan yang tidak mengalami kesulitan dapat dilihat pada Gambar 1:

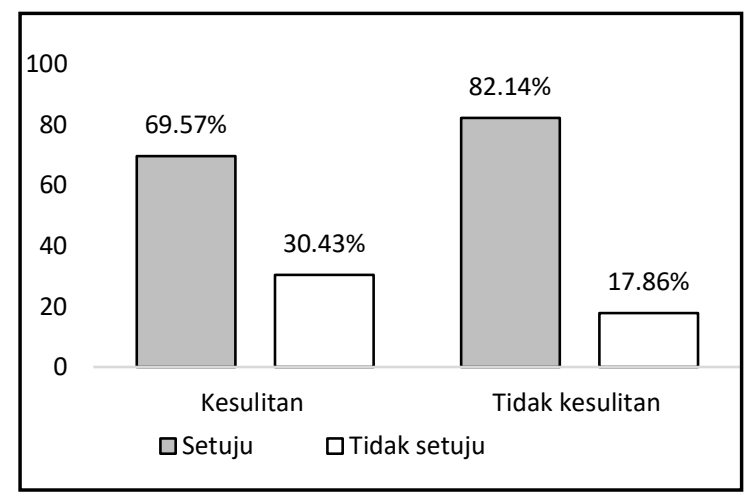

Gambar 1. Grafik perbandingan antara mahasiswa yang mengalami dengan yang tidak mengalami kesulitan dalam pembelajaran Biologi Molekur dengan strategi modified free inquiry

Selanjutnya berdasarkan data pada Tabel 1 juga dapat diidentifikasi penyebab kesulitan mahasiswa dalam pembelajaran Biologi Molekur dengan strategi modified free inquiry. Penyebab kesulitan tersebut dapat dilihat pada Gambar 2:

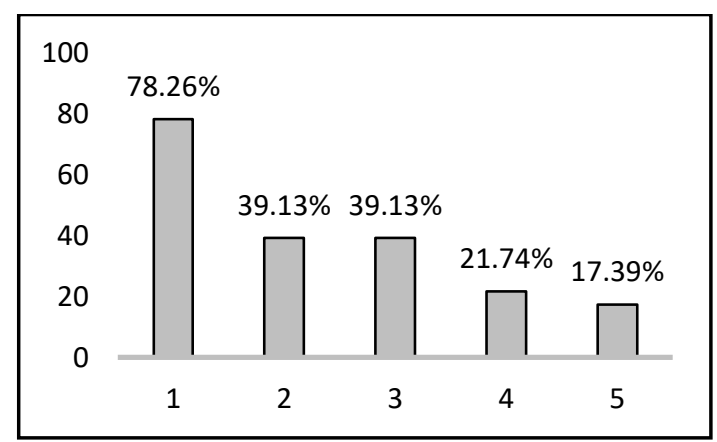

Gambar 2. Grafik penyebab kesulitan mahasiswa dalam pembelajaran Biologi Molekur dengan strategi modified free inquiry: 1. Terbatasnya waktu belajar; 2 . Tidak menemukan bahan-bahan sumber belajar yang memadai; 3. Tidak bisa memahami bahan-bahan sumber belajar yang ditemukan; 4. Tidak mampu mencari bahan-bahan sumber belajar yang memadai; 5. Tidak tertarik dengan strategi modified free inquiry.

Berdasarkan analisis data juga dapat diketahui persentase mahasiswa yang setuju dan tidak setuju terhadap pengaplikasian strategi modified free inquiry pada matakuliah biologi lainnya. Perbandingan mahasiswa yang setuju dan tidak setuju tersebut dapat dilihat pada Gambar 3:

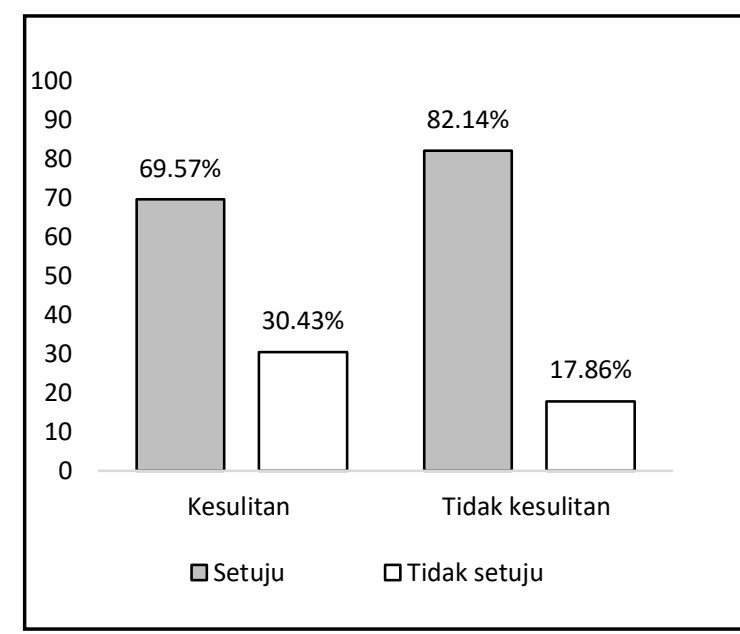

Gambar 3. Grafik perbandingan mahasiswa yang setuju dan tidak setuju terhadap pengaplikasian strategi modified free inquiry pada matakuliah biologi lainnya

\section{PEMBAHASAN}

Pada bagian ini hasil penelitian yang diperoleh diinterpretasi dan dibahas dengan cara membandingkannya dengan teori atau hasil-hasil penelitian yang relevan.

\section{Rasio mahasiswa yang kesulitan dan tidak kesulitan}

Gambar 1 menunjukkan persentase mahasiswa yang mengalami kesulitan dengan yang tidak mengalami kesulitan dalam pembelajaran Biologi Molekuler berstrategi modified free inquiry hampir sama banyak yaitu $45,10 \%$ dan $54,90 \%$, di mana rasionya mendekati $1: 1$. Temuan ini harus menjadi perhatian bagi pendidik 
untuk mengetahui penyebab kesulitan dan mencarikan solusi bagi kepentingan peserta didik. Menurut Johnstone (1980) kesulitan suatu topik kebanyakannya disebabkan oleh pandangan subyektif siswa. Jika siswa sudah memandang topik tersebut sulit maka akan 'mewarnai' pembelajarannya meskipun guru atau dosen menyatakan topik tersebut mudah. Oleh karena itu, tugas pendidik, peneliti, dan perancang kurikulum adalah menelaah mengapa topik tersebut sulit dan bagaimana cara mengatasinya.

Terkait dengan cara mengatasi kesulitan-kesulitan dalam pembelajaran inkuiri, Theis (2016) berpendapat bahwa teknologi dapat digunakan untuk meningkatkan metode pengajaran berbasis inkuiri. Dalam penelitian ini telah digunakan aplikasi virtual laboratory untuk mendukung pembelajaran dan praktikum biologi molekuler, namun didapati masih banyak mahasiswa yang kesulitan dalam pembelajaran. Perlu ditelusuri apakah teknologi virtual laboratory yang digunakan tidak tepat sasaran, tidak efektif, atau malah menyebabkan miskonsepsi bagi mahasiswa.

\section{Penyebab kesulitan yang dialami mahasiswa}

Berdasarkan Gambar 2 diketahui bahwa sebagian besar mahasiswa $(78,26 \%)$ menyatakan keterbatasan waktu sebagai penyebab kesulitan dalam pelaksanaan pembelajaran Biologi Molekuler berstrategi modified free inquiry. Telah umum diketahui dalam kebanyakan penerapan model, strategi, teknik, atau metode pembelajaran bahwa faktor waktu menjadi penyebab terbesar terhambatnya atau tidak sempurnanya keterlaksanaan pembelajaran, termasuk dalam penerapan strategi pembelajaran inkuiri. Hal ini sesuai dengan temuan penelitian Fitzgerald, dkk. (2017) bahwa para guru mengalami pembatasan waktu yang ekstrem sehingga menjadi hambatan dalam penerapan pendekatan berbasis-inkuiri.
Penyebab kesulitan lainnya adalah terkait dengan bahan-bahan sumber belajar, yaitu tidak menemukan bahanbahan sumber belajar yang memadai $(39,13 \%)$, tidak bisa memahami bahanbahan sumber belajar yang ditemukan $(39,13 \%)$, dan tidak mampu mencari bahan-bahan sumber belajar yang memadai $(21,74 \%)$. Pada era digital sekarang, kemampuan peserta didik mengumpulkan informasi dapat sangat cepat dengan bantuan internet. Internet dapat dijadikan jejaring pembelajaran dengan akses dan ketersediaan informasi yang luas dan mudah. Penggunaan internet makin meningkat seiring dengan perkembangan pengetahuan yang pesat. Masa depan menjadi milik peserta didik yang memiliki akses terhadap informasi tanpa batas ini dan mampu memanfaatkan informasi yang diperoleh secepat mungkin (Kemendikbud, 2013). Jika mahasiswa memiliki motivasi yang kuat untuk belajar maka kesulitan terkait sumber belajar tidak akan menjadi hambatan dalam pembelajaran, apalagi kampus sudah menyediakan fasilitas internet yang memadai bagi mahasiswa. Namun, apabila mahasiswa tidak memiliki keinginan dan motivasi yang kuat untuk belajar maka fasilitas yang canggih sekalipun mungkin tidak bermanfaat dalam pembelajarannya. Sebagaimana pernyataan Fitzgerald, dkk. (2017) bahwa kurangnya sumber daya yang baik juga menjadi salah satu hambatan dalam penerapan pendekatan berbasis-inkuiri. Dalam penelitian ini mahasiswa adalah salah satu sumber daya yang terlibat dalam pembelajaran.

Penyebab kesulitan berikutnya yang teridentifikasi adalah ketidaktertarikan dengan strategi modified free inquiry sebesar 17,39\%. Meskipun persentasenya kecil, namun adanya rasa ketidaktertarikan ini dapat mengganggu akvitas pembelajaran. Diduga mahasiswa yang tidak tertarik ini memiliki motivasi intrinsik yang rendah dalam pembelajaran Biologi Molekuler. Dosen atau pendidik dapat memberikan perhatian yang lebih 
besar, pujian atau penghargaan terhadap mahasiswa yang bermotivasi intrinsik rendah untuk meningkatkan partisipasinya dalam pembelajaran. Menurut Reid (2009) bahwa dalam merancang pembelajaran pendidik perlu mempertimbangkan motivasi intrinsik dan ekstrinsik peserta didik untuk memperoleh hasil belajar yang optimal, karena tidak semua peserta didik secara intuitif dan instrinsik termotivasi untuk belajar. Schunk, dkk. (2012) menjelaskan perbedaan antara peserta didik yang bermotivasi intrinsik dan ekstrinsik, yaitu yang termotivasi secara intrinsik mengerjakan tugas-tugas karena tugas tersebut menyenangkan, sedangkan yang termotivasi secara ektrinsik mengerjakan tugas karena dapat menyebabkan berbagai konsekuensi yang diinginkan, seperti mendapatkan hadiah, pujian, atau terhindar dari hukuman.

\section{Dalam penelitian-penelitian} terdahulu ditemukan berbagai kesulitan dalam pembelajaran inkuiri, misalnya siswa SMP mengalami kesulitan memahami materi, mengaitkan hubungan antar konsep, mengerti rumus, dan mengoperasikan rumus untuk menyelesaikan soal dalam pembelajaran inkuiri terbimbing pada pokok bahasan Cahaya (Wijayanti, dkk., 2010). Penelitian Syarkowi dan Malinda (2018) menemukan adanya kendala yang dihadapi siswa SMA dalam model pembelajaran bounded inquiry lab pada konsep Difraksi cahaya oleh kisi, yaitu kesulitan dalam menjawab pertanyaan variabel, kesulitan dalam menentukan alat dan bahan untuk eksperimen, kesulitan dalam menentukan desain eksperimen, kesulitan dalam membuat grafik, dan kesulitan dalam merumuskan konsep secara sistematis. Hasil penelitian Wijayanti, dkk. (2010) dan Syarkowi dan Malinda (2018) tersebut menunjukkan kesulitan yang muncul dari diri peserta didik. Edelson, dkk., (1999) berpendapat bahwa untuk mencapai tujuan akhir dari open-ended inquiry, siswa harus mampu mengatur dan mengelola beragam kegiatan yang kompleks/rumit. Jika siswa tidak dapat mengatur pekerjaan mereka dan mengelola proses yang beragam itu, maka siswa tidak bisa terlibat dalam openended inquiry atau mencapai potensi pembelajaran berbasis-inkuiri. Pendapat Edelson tersebut menyiratkan bahwa peserta didik dengan beragam aktivitas menjadi fokus utama dalam pembelajaran inkuiri, sehingga keberhasilan pembelajaran inkuiri dapat ditentukan oleh kemauan peserta didik untuk terlibat aktif dalam pembelajaran dan kemampuannya untuk mengatur dan mengelola aktivitas yang menjadi tanggungjawabnya.

Peran guru atau pendidik sebagai fasilitator dalam pembelajaran berbasisinkuiri tidak kalah pentingnya dalam menentukan keberhasilan pembelajaran inkuiri. Pendidik yang kurang pengalaman dan kurang memahami hakikat pembelajaran inkuiri dapat menjadi penyebab munculnya kesulitan dalam penerapan pembelajaran inkuiri. Sebagaimana yang dinyatakan oleh Bhagat (2017) bahwa kesulitan dalam penerapan pendekatan pengajaran berbasis-inkuiri adalah terdapat variasi yang substansial terhadap makna pengajaran berbasis inkuiri di antara para pendidik, dan kurangnya pemahaman tentang keterampilan yang diperlukan untuk membantu siswa menghasilkan pertanyaan mereka sendiri. Senada dengan pendapat Bhagat, Fitzgerald, dkk. (2017) menyatakan bahwa kurangnya pengalaman pengembangan profesional pendidik serta kurangnya pemahaman tentang apa sebenarnya pengajaran berbasis inkuiri dapat menjadi faktor penghambat dalam penerapan pendekatan berbasis-inkuiri. Harris dan Rook dalam Lister (2015) menjelaskan bahwa terdapat lima area yang saling berhubungan yang perlu ditangani dalam kelas sains inkuiri K-8, yaitu siswa, tugas, material (bahan ajar), ide sains, dan komunitas kelas. Berdasarkan beberapa temuan dan pendapat peneliti di atas dapat dinyatakan bahwa pendidik merupakan penentu arah keterlaksanaan pembelajaran inkuiri. 
Untuk tugas tersebut maka pendidik terlebih dahulu harus memiliki pengetahuan dan memahami makna inkuiri, memiliki pengalaman berinkuiri, dan aktif terlibat dalam komunitas pendidik dalam rangka pengembangan keprofesiannya.

\section{Prospek penerapan strategi pembelajaran modified free inquiry}

Gambar 3 mengindikasikan bahwa strategi pembelajaran modified free inquiry memiliki prospek yang besar untuk dikembangkan dan diaplikasikan dalam pembelajaran biologi lainnya, karena sebagian besar dari mahasiswa baik pada kelompok yang mengalami kesulitan maupun yang tidak mengalami kesulitan menyatakan setuju jika strategi pembelajaran modified free inquiry diaplikasikan juga untuk matakuliah biologi lainnya. Temuan ini juga diperkuat oleh data pada pertanyaan nomor 6 bahwa sebagian besar mahasiswa $(82,61 \%)$ tertarik dengan strategi modified free inquiry, dan sangat sedikit mahasiswa yang tidak tertarik $(17,39 \%)$.

Ketertarikan mahasiswa terhadap penerapan strategi pembelajaran modified free inquiry sejalan dengan hasil-hasil penelitian terdahulu yang membuktikan bahwa penerapan strategi free inquiry serta modifikasinya memberikan kontribusi yang besar terhadap proses dan hasil pembelajaran. Misalnya Nurkhamid (2014) menyatakan implikasi praktis dari penelitiannya bahwa metode inkuiri bebas termodifikasi memberikan prestasi belajar yang lebih baik dibandingkan dengan metode inkuiri terbimbing, sehingga metode inkuiri bebas termodifikasi dapat menjadi metode alternatif dalam proses pembelajaran materi Sistem Peredaran Darah. Demikian juga Khanafiyah dan Rusilowati (2010) menyimpulkan bahwa pendekatan modified free inquiry dalam pembelajaran menyebabkan kemampuan psikomotorik mahasiswa seperti pembuatan perencanaan, pelaksanaan kegiatan serta pembuatan laporan menjadi lebih baik; jenis eksperimen yang dikembangkan menjadi lebih banyak dan lebih kreatif dalam mengembangkan tujuan eksperimen; serta kreativitas dan kemampuan mahasiswa dalam memahami materi Gelombang meningkat secara signifikan. Hasil penelitian Hadiati dan Pramuda (2016) dalam pembelajaran Fluida Statis menemukan bahwa metode pembelajaran inkuiri terbimbing dan inkuiri bebas termodifikasi berorientasi pendidikan karakter memiliki pengaruh yang signifikan dalam meningkatkan hasil belajar psikomotor, di mana metode inkuiri bebas termodifikasi lebih baik dibandingkan dengan inkuiri terbimbing. Shofiyah (2017) menyatakan bahwa penerapan model modified free inquiry dapat menurunkan miskonsepsi mahasiswa pada level 'sedang' dan dapat meningkatkan pemahaman konsep mahasiswa pada materi Fluida.

\section{KESIMPULAN}

Berdasarkan hasil penelitian dan pembahasan dapat disimpulkan bahwa hampir separuh mahasiswa mengalami kesulitan dalam pembelajaran Biologi Molekuler berstrategi modified free inquiry. Penyebab kesulitan tersebut secara berurutan mulai dari yang terbesar hingga terkecil adalah waktu pelaksanaan pembelajaran yang terbatas, tidak menemukan bahan-bahan sumber belajar yang memadai, tidak bisa memahami bahan-bahan sumber belajar yang ditemukan, tidak mampu mencari bahanbahan sumber belajar yang memadai, dan tidak tertarik dengan strategi modified free inquiry. Sebagian besar mahasiswa baik dari kelompok yang mengalami kesulitan maupun yang tidak mengalami kesulitan setuju jika strategi pembelajaran modified free inquiry diaplikasikan juga untuk matakuliah biologi lainnya. Implikasi dari penelitian ini strategi modified free inquiry dapat diterapkan dalam pembelajaran biologi pada tingkat universitas. 


\section{REFERENSI}

Bhagat, A. (2017). Inquiry-based learning: Assessing students' science inquiry skills. Teacher, 11(4): 34-37

Boulay, R., Parisky, A., dan Campbell, C. (2010). Developing teachers' understanding of molecular biology: Building a foundation for students. ASCILITE Annu. Conf: : 119-128

DeBoer, G.E. (2000). Scientific literacy: Another look at its historical and contemporary meanings and its relationships to science education reform. Journal of Research in Science Teaching, 37(6): 583-599

Duran, M., dan Dökme, I. (2016). The effect of the inquiry-based learning approach on student's critical-thinking skills. Eurasia Journal of Mathematics, Science \& Technology Education, 12(12): 2887-2908. doi: 10.12973/eurasia.2016.02311a

Edelson, D.C., Gordin, D.N., dan Pea, R.D. (1999). Addressing the challenges of inquiry-based learning through technology and curriculum design. Journal of the Learning Sciences, 1-49.

Fitzgerald, M., Danaia, L., dan McKinnon, D.H. (2017). Barriers inhibiting inquiry-based science teaching and potential solutions: Perceptions of positively inclined early adopters. Research in Science Education. doi: 10.1007/s11165-0179623-5

Gormally, C., Brickman, P., Hallar, B., dan Armstrong, N. (2011). Lessons learned about implementing an inquiry-based curriculum in a college biology laboratory classroom. Journal of College Science Teaching, 40(3): 45-51

Hadiati, S., dan Pramuda, A. (2016). Pembelajaran fisika berorientasi pendidikan

karakter dengan metode inkuiri terbimbing dan inkuiri bebas termodifikasi pada materi Fluida Statis. Jurnal Edukasi Matematika dan
Sains, 1(1), 28-30

Johnstone, A.H. (1980). Isolating topics of high perceived difficulty in school biology. Journal of Biology education, 14(2): 163-166

Joyce, B., Weil, M., dan Calhoun, E. (2009). Model-model Pengajaran (terjemahan). Yogyakarta: Pustaka Pelajar

Kemendikbud. (2013). Pendekatan Ilmiah dalam Pembelajaran. Modul HO-2.1-1 untuk Pelatihan Kurikulum 2013. Jakarta

Khanafiyah, S., dan Rusilowati, A. (2010). Penerapan pendekatan modified free inquiry sebagai upaya meningkatkan kreativitas mahasiswa calon guru dalam mengembangkan jenis eksperimen dan pemahaman terhadap materi fisika. Berkala Fisika, 13(2), 714

Lee, C.K., dan Shea, M. (2016). An analysis of pre-service elementary teachers' understanding of inquirybased science teaching. Science Education International, 27(2): 217237

Lister, C.A.P. 2015. A Framework for Implementing Inquiry-Based Learning in the Elementary Classroom. (Tesis). University of Victoria

Martell, C.C. (2019). Barriers to inquirybased instruction: A longitudinal study of history teachers. Journal of Teacher Education, 1-13. doi 10.1177/0022487119841

McClean, P., Johnson, C., Rogers, R., Daniels, L., Reber, J., Slator, B.M., Terpstra, J., dan White, A. (2005). Molecular and cellular biology animations: Development and impact on student learning. Cell Biology Education, 4: 169-179

National Research Council. (1996). National Science Education Standards. Washington, DC: National Academy Press

Nurkhamid. (2014). Pengaruh Pembelajaran CTL dengan Inkuiri Bebas Termodifikasi dan Inkuiri 
Terbimbing terhadap Prestasi Belajar Siswa Ditinjau dari Kreativitas Siswa dan Kemampuan Verbal. (Tesis). Universitas Sebelas Maret, Surakarta

Nurlaila, L., Sriyati, S., dan Riandi. (2017). Analizing student biology education misconception and scientific argumentation ability using diagnostic question clusters (DQC) of molecular genetic concept. IOP Conf. Series: Journal of Physics: Conf. Series, 812, 012112. doi:10.1088/17426596/812/1/012112

Ozcan, T., Ozgur, S., Kat, A., dan Elgun, S. (2014). Identifiying and comparing the degree of difficulties biology subjects by adjusting it is reasons in elemantary and secondary education. Procedia-Social and Behavioral Sciences, 116: 113-122

Quigley, C., Marshall, J.C., Deaton, C.C.M., Cook, M.P., dan Padilla, M. (2011). Challenges to inquiry teaching and suggestions for how to meet them. Science Educator, 20(1): 55-61

Reid, G. (2009). Memotivasi siswa di kelas: Gagasan dan strategi. (Penerjemah: Hartati Widiastuti) Jakarta: PT. Indeks

Rotbain, Y., Marbach-Ad, G., dan Stavy, R. (2008). Using a computer animation to teach high school molecular biology. $J$ Sci Educ Technol, 17: 49-58. doi: 10.1007/s10956-007- 9080-4

Roth, W.M. (1995). Authentic school science: Knowing and learning in open-inquiry science laboratories (ebook). Netherland: Kluwer Academic Publishers. https://books.google.co.id/books?hl=e $\mathrm{n} \& \mathrm{lr}=\& \mathrm{id}=$ wulhBAAAQBAJ\&oi $=$ fnd $\& p g=P T 7 \& d q=o p e n+i n q u i r y+i n+$ scie nce+education \& ots $=\mathrm{gXOHGexbJf \& si}$ $\mathrm{g}=3 \mathrm{cL} 9 \mathrm{Bt}$ 9WcwYQhq782CWOLKYd ojE\&redir_esc $=\mathrm{y} \# \mathrm{v}=$ onepage $\& \mathrm{q}=$ open $\% 20$ inquiry $\% 20$ in $\% 20$ science $\% 20$ edu cation \&f=false. $\quad 10.1007 / 978-94-011$ 0495-1. (Diakses 27 Juli 2017)

Schunk, D.H., Pintrich, P.R., dan Meece,
J.L. (2012). Motivasi dalam pendidikan: Teori, penelitian, dan aplikasi. (Penerjemah: Ellys Tjo). Jakarta: PT. Indeks

Shofiyah, N. (2017). Penerapan model pembelajaran modified free inquiry untuk mereduksi miskonsepsi mahasiswa pada materi Fluida. Science Education Journal, 1(1): 1928. doi: 10.21070/sej.v1i1.836

Syarkowi, A., dan Malinda, S. (2018). Identifikasi kendala siswa dalam proses pembelajaran bounded inquiry lab pada konsep difraksi cahaya. Berkala Ilmiah Pendidikan Fisika, 6(3): 315-324. doi: 10.20527/bipf.v6i3.5058

Theis, J.L. (2016). Technology Predictors of Inquiry-Based Teaching: An Examination of Two K-12 1:1 Pilots. (Disertasi). Bowling Green State University

Tibell, L.A.E., dan Rundgren, C-J. (2010). Educational challenges of molecular life science: Characteristics and implications for education and research. CBE-Life Sciences Education, 9: 25-33

van Hook, S.J., Huziak-Clark, T.L., Nurnberger-Haag, J., dan BalloneDuran, L. (2009). Developing an understanding of inquiry by teachers and graduate student scientists through a collaborative professional development program. Electronic Journal of Science Education, 13(2): 30-61

van Uum, M.S.J., Verhoeff, R.P., dan Peeter, M. (2016). Inquiry-based science education: Towards a pedagogical framework for primary school teachers. International Journal of Science Education, 38(3): 450-469. doi: 10.1080/09500693.2016.1147660

Wijayanti, P.I., Mosik, dan Hindarto, N. (2010). Eksplorasi kesulitan belajar siswa pada pokok bahasan cahaya dan upaya peningkatan hasil belajar melalui pembelajaran inkuiri terbimbing. Jurnal Pendidikan Fisika 
Indonesia, 6: 1-5

Wu, P-H., Wu, H-K., dan Hsu, Y-S. (2014). Establishing the criterionrelated, construct, and content validities of a simulation-based assessment of inquiry abilities. International Journal of Science Education, 36(10): 1630-1650. doi: 10.1080/09500693.2013.871660. 